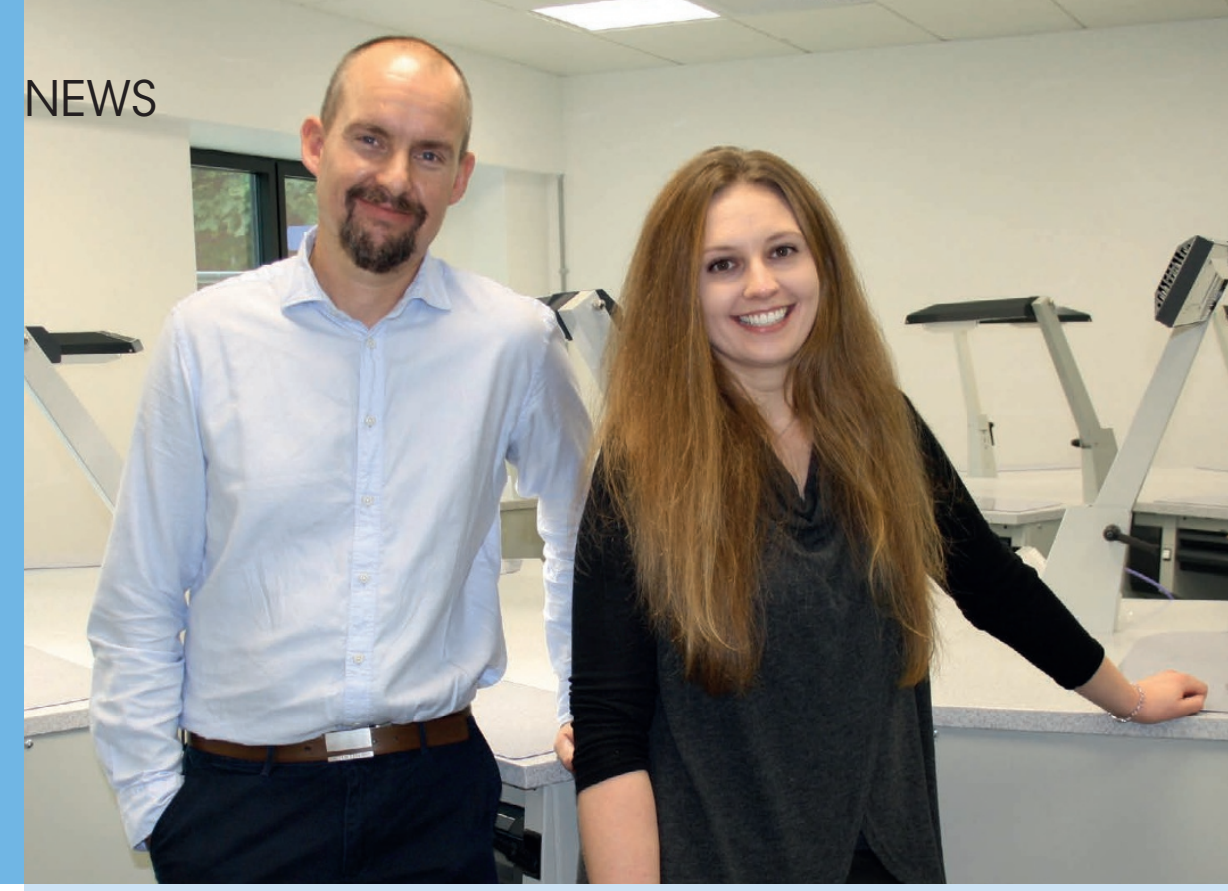

\title{
DENTAL NURSE BECOMES DENTAL TECHNOLOGY APPRENTICE
}

On 5-9 March 2018 Barnet and Southgate College celebrated National Apprenticeship Week (NAW) with a number of activities. The theme this year was 'Apprenticeships Work', showcasing how apprenticeships work for individuals, employers, local communities and the wider economy. A wide array of industry areas are covered in a number of apprenticeships at the College, including dental technology.

Now in its 11th year, NAW 2018 brings together everyone passionate about apprenticeships to encourage more people to choose apprenticeships as a fast-track to a great career and business growth.

Apprenticeships often open doors into a breadth of careers, including dental technology. Barnet and Southgate College's Abby Pulham (pictured on the right) found that to be the case. She commented:

'I'm 26-years-old and studying for the higher level dental apprenticeship at Barnet and Southgate College. I left school at 16 and went to a local college and tried my hand at a number of jobs. I was a dental nurse for four years and whilst there I really wanted a change, so I started looking at other opportunities in the industry and started contacting dental labs in the area. That's when I contacted Adam Norris for a work placement, and I was successful so started working for his dental laboratory as an assistant trainee dental technician. My course is three years long coming in one day a week to the Southgate campus dental facility and four days a week I'll be working in Chelmsford. The degree level apprenticeship really appealed to me as I didn't have a formal qualification as such and didn't go on to university after school in a conventional route, so I really wanted to get a degree under my belt. I'm enjoying my course and gaining a qualification whilst earning a wage at the same time.'

Adam Norris (pictured on the left) owns Adam Norris Dental Laboratories and employs Abby. He said:

'We're based in Chelmsford and opened in 2002. Barnet and Southgate College informed me of their new dental facility and the range of courses they would offer. It sounded fantastic, a lot of investment and thought has clearly gone into the facility and the types of courses delivered. The apprenticeship really appealed to me as I wanted one of my employees to continue working with me, but train at the same time. I'm a clinical dental technician and traditionally we train up technicians from scratch or they come to us from other commercial laboratories. We do all of our own clinical work at our organisation so we see our own patients directly, we specialise in prosthetics and also have a denture clinic, so we have private clients. I needed a fully trained technician, which would look at the clinical aspects as well. Abby had a plan to train as a technician as well, so it was a good opportunity to sign up an apprentice. The Barnet and Southgate dental facility is really convenient for us. Often laboratory owners send their people off for training and don't have much contact with the provider, but I want to be more hands on and see what Abby will be doing at College as part of her higher level apprenticeship. It makes me want to come back and train as everything is brand new and state-of-the-art.'
HELP KICK OFF

\section{A SUMMER OF} SMILES

The Oral Health Foundation has announced the return of National Smile Month, which this year will take place between 14 May and 14 June, aiming to increase awareness

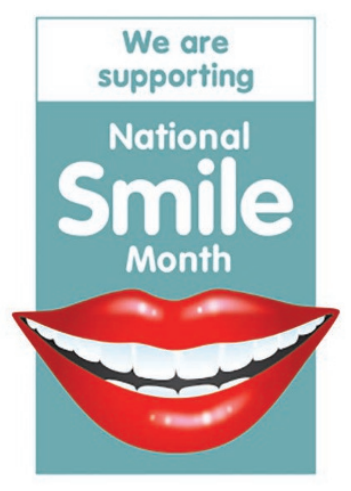
of important oral health issues and make a significant difference to the wellbeing of millions of people.

Supported by thousands of individuals and organisations, National Smile Month promotes three key messages at the heart of good oral health:

- Brush your teeth last thing at night and on at least one other occasion with a fluoride toothpaste

- Cut down on how much and often you have sugary foods and drinks

- Visit your dentist regularly, as often as they recommend.

The charity is calling on dental, healthcare, education professionals and support from the voluntary sector to help spread smiles and key oral health messages even further than ever before.

Chief Executive of the Oral Health Foundation, Dr Nigel Carter OBE, said: 'Last year, the campaign reached unprecedented levels, with in more than 4,000 organisations pledging their support in promoting better oral health. This year we want it to be even bigger and better.

'Much of the credit for the improvement we have seen in oral health over recent years is down to hard working supporters and volunteers who reach out to their local communities.

'With your support the campaign reaches more than 50 million people each year and we are delighted to see how many of you actively get involved in National Smile Month'

National Smile Month 2018 sees the return of the now iconic Smiley, something which Dr Carter believes symbolises exactly the purpose of the campaign.

To find out more about the campaign and to get involved, visit www.smilemonth.org. 